\title{
THE EVIL INCLINATION IN THE DEAD SEA SCROLLS, WITH A RE-EDITION OF 4Q468I (4QSECTARIAN TEXT?)
}

\author{
Eibert Tigchelaar
}

In a contribution to the Dictionary of Deities and Demons in the Bible, Piet van der Horst introduced the 'evil inclination' as follows: 'The concept of an evil inclination is typically rabbinic. This notion does not occur in the Bible, but the rabbis did derive it from biblical texts (esp. Gen $2: 7 ; 6: 5 ; 8: 21)$. This inclination or drive is sometimes personified as a demonic figure or the Satan. ${ }^{11}$ In his discussion of the 'evil inclination' he therefore almost exclusively refers to rabbinic texts, although he mentions the possibility that the theory of two yesarim (inclinations, desires, drives, bents of mind') 'may have had precursors in writings such as Test. Asher 1:3-9 and 1QS 3:13-14'. ${ }^{2}$ Boyarin, however, points out that there were different rabbinic views on the evil inclination (or, in his words, 'evil desire'), namely a dualistic one 'considering the human will to be composed of good and evil instincts at war with each other' and a monistic, dialectical one. ${ }^{3}$ The question then is what exactly was the rabbinic innovation, and to what extent is there a development from Genesis to the rabbis. There is no lack of studies that argue that the use of the term yeser or the concept of an evil inclination in Second Temple Judaism differs essentially from that of the rabbis. ${ }^{4}$ Most studies on the evil inclination in the Dead Sea Scrolls stem from before the publication of the Cave 4 fragments, ${ }^{5}$ and the first objective of this

\footnotetext{
${ }^{1}$ P.W. van der Horst, 'Evil Inclination יצר הרע', in: K. van der Toorn et alii (eds), Dictionary of Deities and Demons in the Bible. Second Extensively Revised Edition, Leiden 1999, 317-19, at 318-19. See also P.W. van der Horst, Het vroege jodendom van A tot Z: Een kleine encyclopedie over de eerste duizend jaar, Zoetermeer 2006, 10 (lemma 'Aandrift (jetster))'.

2 Van der Horst, 'Evil Inclination', 318.

${ }^{3}$ D. Boyarin, Carnal Israel: Reading Sex in Talmudic Culture, Berkeley 1993, 64-5.

${ }^{4}$ See esp.J. Hadot, Penchant mauvais et volonté libre dans la Sagesse de ben Sira (L'Ecclésiastique), Brussels 1970, and G.H. Cohen Stuart, The Struggle in Man between Good and Evil: An Inquiry into the Origin of the Rabbinic Concept of Yeser Hara', Kampen 1984. See also H. Lichtenberger, 'Zu Vorkommen und Bedeutung von יצר in Jubiläenbuch', ZSF 14 (1983), 1-10. The opposite view, namely of the attestation in the second century BCE of the concept of two inclinations, is argued for by J. Cook, 'The Origin of the Tradition of the יצר הרע and יצר הטוב', FS7 38 (2007), 80-91.

${ }^{5}$ See R.E. Murphy, 'Yẹșer in the Qumran Literature', Biblica 39 (1958), 334-44;
} 
contribution is to present a brief overview of the references in the scrolls, and to evaluate the Dead Sea Scrolls' innovations relating to the evil inclination. The second part of this paper will present a new reading of a Qumran Cave 4 prayer fragment that mentions the 'evil inclination of our heart'. ${ }^{6}$

\section{The Evil Inclination in the Dead Sea Scrolls}

According to the most recent concordance, the noun יצר is found seventy-six times in the non-biblical Dead Sea Scrolls. ${ }^{7}$ This number includes six overlaps, parallel textual occurrences in different manuscripts, ${ }^{8}$ resulting in seventy cases. ${ }^{9}$ It is not the purpose of this contribution to discuss all of these occurrences, of which more than half are found in one manuscript, 1QH ${ }^{\mathrm{a}}$. Instead, I will focus on those cases where the noun יצר is qualified explicitly as evil.

fub. 35:9 '... For you know the inclination of Esau, that he has been evil from his youth...' has been largely preserved in 1Q18 (1QJub $\left.{ }^{\mathrm{b}}\right)$ 1-2 3 and 4Q223-224 (4QJub $\left.{ }^{\mathrm{h}}\right) 2$ i 49, the combined evidence of כי יודע אתה את יצר עשו אשר which indicates that the Hebrew text read (הוא) רע מן נעוריו xellin $\bar{a},{ }^{11}$ Lichtenberger has examined whether the other occurrences of xellinā in Fubilees might also reflect Hebrew ציצ', but the uncertainties of retroversion are illustrated by $\mathcal{F} u b .5: 2$, where the plausible assump-

Cohen Stuart, Struggle in Man, 94-100; H. Lichtenberger, Studien zum Menschenbild in Texten der Qumrangemeinde, Göttingen 1980, 77-81 (esp. on the יצר in the Hodayot).

${ }^{6}$ It is fitting to dedicate this re-edition of a tiny prayer fragment to Piet van der Horst, my teacher in 1978-79, and a colleague in more recent years, who has an ongoing interest in the evil inclination, prayer texts, and Qumran.

7 M.G. Abegg, Jr. et alii, The Dead Sea Scrolls Concordance. Volume One: The Non-Biblical Texts from Qumran, Leiden 2003, 319. The Accordance module Qumran Sectarian Manuscripts 2.6, lists 75 cases (ignoring words inside brackets), omitting 4Q418 43-45 i 13.

${ }^{8}$ CD II 16 // 4Q270 1 i 1; 1OS VIII 3 // 4Q259 II 11; 10H 35 // 4Q428 13 8; 1QH XXIII 12 // 4Q428 14 3; 4Q416 $116 / /$ 4Q418 2 + 2a-c 8; 4Q417 1 i $17 / /$ 4Q418 43-45 i 13 (using the references utilized in the Concordance).

9 A few may be considered uncertain or disputed. E.g., is יצרו in 4Q417 1 i 17 // 4Q418 43-45 i 13 a noun with suffix ('his inclination') or verb with suffix ('he formed him')? Also in 4Q299 86 and 7 it is not certain whether יצר is a noun or verb.

${ }^{10}$ See the discussions in Lichtenberger, 'Vorkommen und Bedeutung', 5-6, and J.C. VanderKam, Discoveries in the Fudaean Desert XIII, Oxford 1994, 105.

${ }^{11}$ The noun xellina $\bar{a}$ is related to the verb xallaya, 'to consider, think, devise'. Chr.Fr. A. Dillmann, Lexicon Linguae Aethiopicae cum indice latine, Lipsiae 1865, 579, indicates that xellinā renders Greek $\mu \varepsilon \lambda \varepsilon \dot{\varepsilon} \eta, \lambda$,

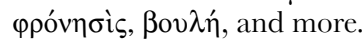


tion that xellina $\bar{a}$ corresponds to יצר of Gen 6:5 is not validated by the traces in 11Q12 (11QJub) 74 . Nonetheless, one may agree with him that there is no evidence of an external evil inclination that works in the human heart. The verses in fubilees that refer to a xellinā refer to human reasoning which is located in one's heart.

In 4Q370 (4QAdmonition Based on the Flood) 1 i 3 the text reads (ישפטם יהוה כ[כ]ל דרכיהם ומחשבות יצר לבם ה] 'And YHWH judged them according to [al]l their ways and according to the thoughts of the [evil] inclination of their heart'. ${ }^{2}$ Even though יצר is badly damaged and רע is lost in a hole of the manuscript, the available space and the context make this reading highly plausible. The other references in this fragment to the Genesis account of the flood indicate that this line refers to Gen 6:5b וכל יצר מחשבת לבו רק רע, 'and every inclination of the thoughts of their hearts (sc. of mankind) was only evil'. The difference of order, from מחשב(ו)ת יצר to יצר מחשב(ו)ת is not due to free quotation, but seems to reflect a general interchangeability of the two collocations. ${ }^{13}$ This variation, as well as the fact that in the three LXX renderings of יצר מחשבות the Greek has only one word indicating thought or planning for the two Hebrew terms, ${ }^{14}$ should warn us to put too much emphasis on the use of the noun יצר. Whatever the case, 4Q370 does not in itself suggest a concept of an evil inclination different from that of Gen 6:5.

It has been suggested that another case of יצר רע is found in 4Q422 (4QParaphrase of Genesis and Exodus) I I 12, ביוצר רע ולמעש]י רשעה,

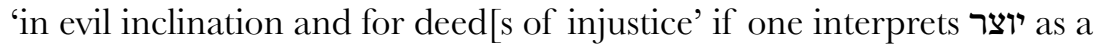
qutl form of יצר. The fragment is small and damaged, but seems to be related to Gen 2-3, the preceding line 'he rose against Him and they forgot' referring to the first sin in Gen 3. Elgvin therefore argues that the use of יצר רע here, and not in the context of the flood generation, indicates a conscious reflection on the beginning of sin on earth with

\footnotetext{
${ }^{12}$ Edited by C. Newsom in Discoveries in the Fudaean Desert XIX, Oxford 1995, 85-97.

${ }^{13}$ In Gen 6:5 the יצר מחשבות is qualified as evil, whereas in 1 Chron 28:9 and 29:18 the phrase is used in a neutral sense. In 4Q381 76-77 2 and 4Q525 74 there is not enough context to determine how יצר מחשבות is characterized. On the other hand, all Dead Sea Scroll attestations of מחשבות יצר are used negatively. In CD II 16 and 4Q286 7 ii 7-8 (par 4Q287 6 7) the יצר is qualified as of אשמה, 'guilt'; in the above mentioned phrase of 4Q370 and in 4Q417 1 ii 12 (see below) the יצר is called, whereas the context of 1 QS V 5 shows that it is negative there too.

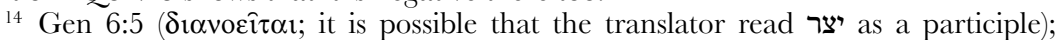

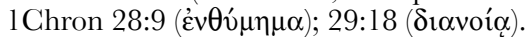

${ }^{15}$ Edited by T. Elgvin in DfD XIII, 421-23.
} 
Adam'. ${ }^{16}$ However, there is no reason why one should not choose the easier reading of a participle יוצר, and read 'by the planner/former of evil'. In either case, it is noteworthy that a few lines earlier (line 7) this short fragment has a reference to a holy spirit, and one may speculate on a dualistic background of this fragment.

The reference to an 'evil inclination' in 4Q417 (4QInstructionc) 1 ii 12 is given in the instruction אל תפתכה מחשבת יצר רע, 'Let not the thought of an evil inclination seduce you'. The context is too fragmentary to specify whether the 'thought of an evil inclination' is here of a general or a more specific (e.g. sexual) nature. ${ }^{17}$

Different from the previous occurrences are two cases of יצר רע in a context that does not refer to thoughts or to the human heart. The first is the much-discussed prayer in the so-called Plea for Deliverance in the Cave 11 Psalms Scroll (11Q5 XIX). ${ }^{18}$ The prayer asks God for forgiveness and purification, and to be granted a spirit of faithfulness אל תשלט בי שטן ורוח :-16-15 knowledge, and then reads in lines טמאה מכאוב ויצר רע אל ירשו בעצמי ,Let not a satan rule over me, nor an unclean spirit; neither let pain nor evil inclination have power over my bones'. ${ }^{19}$ Soon after the publication of this prayer, Flusser published an article in which he discussed the trajectory from Ps 119:133 'let not iniquity rule over me' via Levi's Prayer in the Aramaic Levi Document and the Plea for Deliverance, to three later Jewish prayer texts, in which 'iniquity' (און), (any) satan, unclean spirit, evil inclination, and physical affliction are associated, and in part interchanged. ${ }^{20}$ Whereas in 11Q5 'satan and unclean spirit' replace 'iniquity' of the Ps 119 prayer, in the later rabbinic prayers 'iniquity' is replaced by 'the evil inclination'. The formulation in Levi's Prayer, אל תשלט בי כל שטן, 'Let not any

${ }^{16}$ Elgvin, DfDD XIII, 423.

${ }^{17}$ Cf. J. Strugnell \& D.J. Harrington S.J., in: DfD XXXIV, Oxford 1999, 171-2. D.J. Harrington S.J. Wisdom Texts from Qumran, London/New York 1996, 56 associates this verse with 'the yeseser ra' that can cause a person to sin'.

${ }_{18}$ First edition: J.A. Sanders, DFD IV. The Psalms Scroll of Oumran Cave $11\left(110 \mathrm{Ps}^{a}\right)$, Oxford 1965, 76-9. Large portions of the same psalm have also been preserved in $11 \mathrm{Q} 64-5$.

${ }^{19}$ For ירשו as derived from רשה instead of ירשו), see R. Polzin, 'Notes on the Dating of the Non-Massoretic Psalms of 11QPsa', HTR 60 (1967), 469-70, n.9.

${ }^{20}$ D. Flusser, 'Qumrân and Jewish "Apotropaic” Prayers', Israel Exploration Fournal 16 (1966), 194-205 (this publication has been overlooked by both Hadot, Penchant mauvais, and Cohen Stuart, Struggle in Man). Dutch translations of the Greek version of Levi's Prayer and of the prayer in b.Ber 16b which is recited in the Amidah, have been provided by P.W. van der Horst, Gebeden uit de Antieke Wereld, Kampen 1994, 60-1 and 87. 
satan rule over me', as well as the formulations in other texts, indicate that שטן is a category of evil spirit, and not a proper noun. ${ }^{21}$ It is not entirely certain how the 'evil inclination' in the Plea for Deliverance is to be understood, whether as an outward or as an inward force, but in any case it seems to have gained a substance of its own, independent of a human's heart.

Comparable is the case in the Barkhi Nafshi text (4Q434-438), where the hymnist sings: יצר רע גער]תה, 'evil inclination [you] have rebuked' (4Q436 1 i 10).22 The editors reconstruct the entire phrase as follows: The evil inclination [you] have driven with rebukes [from my innermost parts and the spirit of ho]liness you have set in my heart'. ${ }^{23}$ The clause is part of a longer hymnic section referring to the removal of 'adulterousness of the eyes', the sending away of 'the stiffness of neck', the removal of 'wrathful anger', and the carrying away of 'haughtiness of heart and arrogance of eyes'. The 'evil inclination' may belong to the same category of the following vices, especially since the combination of 'thoughts of a guilty inclination' and 'adulterous eyes' is also found in CD II 16. On the other hand, the verb גער, 'to rebuke', is commonly used with satan or evil spirits, and the question is whether here the verb is used metaphorically, as a mere synonym of שלח or, 'remove' or 'send away', or in a more technical sense. From a literary perspective, one must observe the intertextual relation of the Barkhi Nafshi text with Zech 3: 4Q436 1 i-ii and 4Q437 4 (par 4Q438 4 ii) use the verbs of Zech 3, גער המפריר, but also

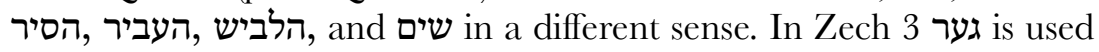
to rebuke the Satan, and the other verbs refer to the change of clothing and apparel of the high priest Joshua. In the Barkhi Nafshi text the

${ }^{21}$ J.C. Greenfield et alii, The Aramaic Levi Document: Edition, Translation, Commentary, Leiden 2004, 129-31. Cf. also תגער בכול שטן משחית you will rebuke every destructive satan' in 1QH ${ }^{a}$ XXII 25; כל שטן ומשחית 'every satan and destructive' in 1QH ${ }^{a}$ XXIV

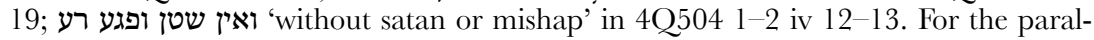
lelism of פגע רע and the rabbinic prayers, see Flusser, 'Qumrân and Jewish "Apotropaic" Prayers', 199.

${ }_{22}$ M. Weinfeld \& D. Seely, in: DfD XXIX, Oxford 1999, 297.

23 The reconstruction רוח קוד] is based on the context, but foremost on Ps 51:13. Note that the preceding clause has the לב טהור of Ps 51:12. Note how Flusser, 'Qumrân and Jewish "Apotropaic" Prayers', 203-04, without any knowledge of the Barkhi Nafshi texts, already referred to Ps 51 as a remote ancestor of this type of prayer. Also the Greek version of Levi's Praver, preserved in the Mount Athos (Ms e) manuscript of

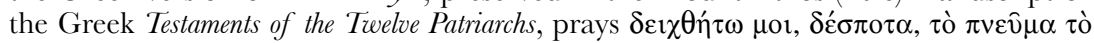
öriov. 
clothing and apparel has been replaced by virtues and vices, whereas God's rebuke of the Satan in Zechariah corresponds to the rebuke of the evil inclination..$^{24}$ From a phenomenological perspective, one may observe that there is not always a clear distinction between virtues and vices, and spirits as personifications of those virtues and vices. Both in the Plea for Deliverance and in the Barkhi Nafshi texts these vices (and virtues) are connected with bodily parts, and one is reminded of later magical texts which refer explicitly to spirits that can take possession of bodily parts and influence a person's behaviour. ${ }^{25}$ In both texts the 'evil inclination' is something extraneous to man, that can enter its body, but also can be rebuked.

Those few explicit references to an 'evil inclination' in the Dead Sea Scrolls indicate on the one hand the influence of Gen 6:5, which relates the 'evil inclination' to 'thoughts' and the 'heart', and on the other hand a new development where the 'evil inclination' is personified, perhaps in the form of a spirit. Two issues are of importance. First, the personification of the 'evil inclination' is part of a broader attested tendency to personify virtues and vices. Second, in 4Q436 (Barkhi Nafshi) this personified 'evil inclination' has become part of a dualistic system. This innovation can best be illustrated by quoting Flusser, who describes the differences between the prayers found near Qumran and Ps 51: 'the Psalm does not demonize the sin-no Satan, impure spirit or spirit of wickedness is named as a counterpart of the Holy Spirit and the right, willing spirit. ${ }^{26}$ 4Q436 $1 \mathrm{i}$-ii, in using elements of Ps $51,{ }^{27}$ however, does exactly that: in rebuking the 'evil inclination' it demonizes $\sin ^{28}$ From a systemic point of view, this innovation can best be explained as influenced by the Iranian dualism and the character of the Zoroastrian spiritual entities as designating at the same time a 'psychological faculty,

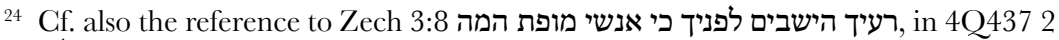
i עדת אנשי] מופת הושבת לפני 12 ,the congregation of men] of portent you have made to sit before me.

${ }_{25}$ Cf. more in detail my 'Catalogue of Spirits, Liturgical Manuscript with Angelological Content, Incantation? Reflections on the Character of a Fragment from Qumran (4Q230 1). With Appendix: Edition of the Fragments of IAA \#114', in: M. Labahn \& L.J. Lietaert Peerbolte (eds), A Kind of Magic: Understanding Magic in the New Testament, Its Ancient Environment and Its Later Impact, London/New York 2007, 133-46.

${ }^{26}$ Flusser, 'Qumrân and Jewish "Apotropaic" Prayers', 204.

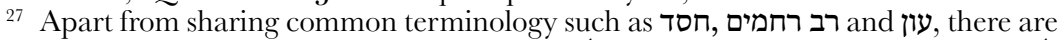

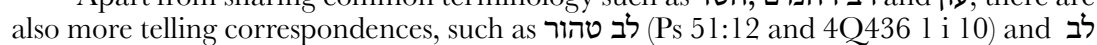
נדכה (Ps 51:19 and 4Q436 1 i 1).

${ }_{28}$ Cf. also רוח שקר אבדת, 'a spirit of deceit you have destroyed' in 4Q435 2 i 5.
} 
a metaphysical entity and a divine being (angel or demon) ${ }^{2}{ }^{29}$ However, as García Martínez has pointed out: 'in its fully developed form it is only found in the writings of the Sassanian period. So, in the end we lack the linguistic link'. ${ }^{30}$

If one compares the Dead Sea Scrolls to the rabbinic concept of the evil inclination, one may perceive several precursors. The association of the 'guilty inclination' and 'evil inclination' with the 'adulterous eyes' in CD II 16 resp. 4Q436 may be seen as the backdrop of the rabbinic association of the 'evil inclination' with the sexual urge. ${ }^{31}$ Also, the ethical dualism of the Barkhi Nafshi texts which, if the editors' reconstruction is valid, opposes the 'evil inclination' to the 'holy spirit' may be a large step towards the rabbinic dualism. Thirdly, the juxtaposition of satan and 'evil inclination' in the Plea for Deliverance reminds one of the identification of Satan and evil inclination in some Talmudic texts (b.BB 16a). ${ }^{32}$

Scholars have emphasized that the rabbinic concept of the 'good inclination' as opposed to the 'evil inclination' is not attested in the Dead Sea Scrolls and Second Temple Judaism, although these texts abound with ethical, cosmological and anthropological dualism. Reference is often made to 1QS III 13-IV 24, the Two Spirits Treatise, which in III 18-19 refers to 'two spirits' entrusted to man, the spirits of truth and injustice. Yet, the dualism found in most Dead Sea Scrolls is not anthropological, but manifested in opposing spiritual beings, which are named and characterized differently in the separate scrolls. On the other hand, the rabbinic dualistic theory of a 'good inclination' and an 'evil

\footnotetext{
${ }^{29}$ S. Shaked, 'Qumran and Iran: Further Considerations', Israel Oriental Studies 2 (1972), 433-46 at 436. Cf. also Tigchelaar, 'Catalogue of Spirits'.

${ }^{30}$ F. García Martínez, Qumranica Minora 1: Qumran Origins and Apocalypticism, Leiden 2007, 237. He continues: 'Therefore, although the influence of Iranian dualism on the development of the Dualism of the Dead Sea Scrolls provides the best available explanation, and due to the presence of the same general theme and several concrete details can be considered probable, it cannot be considered proved.'

${ }^{31}$ Cf. the suggestion by Boyarin, Carnal Israel, 63: 'My hypothesis is that the Rabbis inherited the term "Evil Instinct" from a first-century Judaism much more averse to sexuality than they were, and unable to dispense with it, they ironized the term'.

${ }_{32}$ Cf. e.g. Cohen Stuart, Struggle of Man, 214-18.
} 
inclination' is relatively rare, and it is questionable whether the rabbis embraced one specific concept of the 'evil inclination'. ${ }^{33}$

\section{A Re-edition of $4 Q 468 i$}

A hitherto unnoticed and unrecorded mention of an evil inclination is found in the small fragment 4Q468i, which was published as '4QSectarian Text?' ${ }^{34}$ The editor transcribed and translated the fragment as follows:

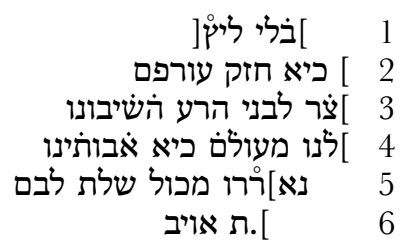

1. ]without scorning[

2. ]because their neck is hard

3. ]enemy? to the sons of evil, they returned us

4. $l$ us from eternity, because our fathers

5. ]they [were cu] rsed because of all the insolence of their hearts

6. ].t enemy

The editor characterizes the fragment as a Sectarian Text: 'By contrasting recalcitrant sinners (כיא חזק עורפם, 'because their neck is hard', line 2; לבני רע, 'for the sons of evil', line 3) with a group of insiders (referred to in first and third plural [השיבונו, 'they returned us!']), 4QSectarian Text expresses the idea of a chosen minority which understands itself as separated from the evil, sinful majority of the people' ${ }^{35}$ Recognizing that the fragment has some aspects of penitential prayer ${ }^{36}$ he suggests that the fragment may have been 'part of a historical sketch of the

33 Cf. the somewhat provocative statements in Boyarin, Carnal Israel.

34 A. Lange, '4Q468i. 4QSectarian Text?', in: DfD XXXVI, Oxford 2000, 416-17. The transcription and translation of this fragment are also found in D.W. Parry \& E. Tov (eds), The Dead Sea Scrolls Reader 6: Additional Genres and Unclassified Texts, Leiden 2005, 306-07. This is not the same fragment presented as '4Q468i 4QHistorical Text H' in F. García Martínez \& E.J.C. Tigchelaar, The Dead Sea Scrolls Study Edition, Leiden 2000², 946-47, which is now officially referred to as '4Q468f 4QHistorical Text G'.

35 Lange, '4Q468i,' 416. Note the typo הרע for.

36 Lange refers to J.M. Baumgarten, who was the editor of the other fragments from the same Museum Plate, namely 4Q264a (4QHalakha B) and 4Q284 (4QPurification Liturgy). 
founding of the community (cf. CD I) or as a confession of sins (cf. e.g. 1QS I 24-II 1)', and mentions 'the contrast between recalcitrant sinners and a changed group of insiders'. The comments are brief, and neither discuss issues such as the strange phrase בני הרע, nor why the first person plural in השיבונו would refer to a 'changed group of insiders', ${ }^{37}$ nor who these 'recalcitrant sinners' are. Line 3 seems to be crucial for Lange's interpretation, but the translation of this line does not impart much meaning to the text.

In a few cases the reading of the fragment should be corrected ${ }^{38}$ The most important are the following: in line 2 the last word is עורפנו, 'our neck', and not עורפם, 'their neck'; in line 3 read לבנו and not לבני 2 I also suggest different readings in lines 1 and for the first word of line 5, but those are of minor importance. My reading is as follows:

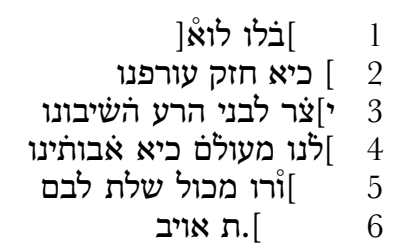

Unvocalised Hebrew in fragmentary context is often ambiguous. Some words may therefore be understood different from the DJD edition. In line 2, חז may be an adjective ('our neck is hard'), or a piel perfect ('he hardened our neck'). ${ }^{40}$ In line 3, I read צר לבנו הרע [', 'the evil inclination of our heart', ${ }^{41}$ as against the editor's צר לבני הרעו הרע [יבעו, 'enemy? to the sons of evil'. The last word of the line, השיבונו, can be a perfect third plural with suffix, an imperative with suffix, or a perfect first plural. In line 5 שלת לבם need not be 'the insolence of their hearts', which would be a

\footnotetext{
37 'Changed' because of the verb השיבונו? Also, it is not clear to me why the use of first person plural forms implies a 'group of insiders'.

${ }_{38}$ See the photograph in $D F D X X X V I$, pl. XXIX, taken from the PAM photograph 43.310. Cf. also PAM 41.707.

${ }^{39}$ In this hand the main distinction between waw and yod is the larger, triangular head of the latter, compared to the hooked head of waw.

${ }^{40}$ The choice for adjective or perfect (or even imperative!) is related to the understanding of the genre of the text. If the text is a confession, than we may read an adjective, but if it presents an historical overview, then read a perfect. Note that the phrase deviates from the common collocation קשה (adjective or hifil) with ערף to express stiffneckedness.

${ }^{41}$ Grammatically, the clause may also be translated 'the inclination of our evil heart'.
} 
rare Aramaism, ${ }^{42}$ but can also be 'the desire(s) of their heart' ${ }^{43}$ In view of the association of the evil inclination with sexual desire or desires in general, I prefer 'desire' above 'insolence'. Different interpretations might even be offered for the form מעולם, which one normally would read as 'from eternity', 'from old'. ${ }^{44}$

The most important changes vis-à-vis the editor's transcription and interpretation are in lines 2 and 3. The corrected reading shows that there is no contrast between 'recalcitrant sinners' and the first person plural ('a group of insiders'); the speakers themselves are the recalcitrant sinners. Line 3 does not have the unique phrase 'sons of (the) evil', ${ }^{45}$ which might indeed have suggested polemics against outsiders, but 'the evil [in]clination of our heart', the phrase which was also attested in 4Q370 1 i 3 (though there with the third person plural suffix), and which qualifies not the outsiders but the speakers as sinners. ${ }^{46}$ In short, what we have here are first person plural utterances in lines 2, 3, and 4 , and references to others in lines 4 and 5. In line 4 those are 'our fathers', whereas 'their' in line 5 in 'their heart' might also refer to the fathers. In view of these forms, it is best to interpret השיבונו also as a perfect first person plural form, rather than as a reference to a third person plural with first person suffix. Lack of context precludes a precise understanding of השיב here.

First person plural forms are relatively rare in the Dead Sea Scrolls, and are found predominantly in hymns or prayers. Thus, e.g., אבותינו, 'our fathers', occurs some thirteen times in the Scrolls, but only once or twice in a non-hymnic/prayer setting. ${ }^{47}$ In half of the cases ${ }^{48}$ references to 'our fathers' are found in confessions of the sins of the speakers, who

${ }^{42}$ Lange, '4Q468i', 417, refers to Dan 3:29 ketiv שלה, 'insolence', which derives from Akkadian šillātu or šillatu.

43 For שלה as an orthographic variant of שלתלה cf. 1 Sam 1:17. For other examples of dropping of radical (quiescent) alef in medial position cf. E. Qimron, The Hebrew of the Dead Sea Scrolls, \$100.61. For the expression שאלת לב cf. Ps 37:4 משאלות לבך.

44 Note also that syntactically מעולם at the end of a sentence is not quite usual.

45 The phrase בני הרע is neither attested in the Hebrew Bible nor in the Dead Sea

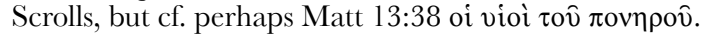

46 Cf. below for the different forms of the expression 'evil inclination.'

47 CD XX 29; 1QS I 25-26; 1QM XIII 7; XIV 8; 4Q266 11 11; 4Q381 46a+b 4 (?); 4Q393 3 6; 4Q504 1-2 ii 8; vi 6; 4Q506 131-132 12. In a curse 4Q377 2 ii 5. The genre in 4Q392 6-9 3 (if 'fathers' are to be read here at all) is not clear. References to 'my fathers' or 'our fathers' are also found in other early Jewish prayers.

${ }_{48}$ CD XX 29; 1QS I 25-26; 4Q504 1-2 ii 8; vi 6; 4Q506 131-132 12. 
confess they have sinned as their fathers. References to the stiffneckedness of the fathers can be found in Neh 9:16 and in 4Q506 131-132 13 (par 4Q504 4 7) where these fathers are called 'stiffnecked' (קשו עורפם). The 'evil heart' is found mainly in Jeremiah, in the clause שררות לבם (לבורפי (49) 'stubbornness of their/his evil heart', in prophetic sermons that sometimes compare the iniquities of the present people to those of the fathers..$^{50}$ In this context of sins, one might even speculate on the possibility that מעולם is not 'from eternity', but 'their disloyalty', the root מעל being a stock element in the confession of sins. ${ }^{51}$

The first person plural's confession of stiffneckedness and evil inclination can only, it would seem to me, be read either as part of a historical review, in which it would refer to the past, or as part of a confession or penitential prayer. ${ }^{52}$ The perfect השיבונו may suggest the former, but the overall correspondence with the prayers mentioning the speakers' iniquities in connection to that of their fathers, suggests the latter. The lack of a second singular address to God makes it difficult to decide whether the fragment contains only a confession, or also a petition.

In neither case is there any reason to qualify this fragment as a specifically sectarian text. The text does not contrast insiders with outsiders, but the first person plural speakers confess or refer to their guilty state before God. The interest of this small fragment is that it presents the first case where the evil inclination of one's heart is not attributed to sinful others, but is part of a confession of one's own human nature.

\footnotetext{
${ }^{49}$ Jer $3: 17 ; 7: 24 ; 11: 8 ; 16: 12 ; 18: 12$.

50 Jer $7: 22-24 ; 16: 10-12$.

51 Reconstruct, for example, אל תזכור [לנו מעולם, 'do not account] to us their disloyalty'. However, for 'their disloyalty', one would either expect the noun מעל מלנור with suffix, or the infinitive construct with suffix according to the כותבם rather than the כתובם pattern. Cf. for those patterns Qimron, The Hebrew of the Dead Sea Scrolls, §311.15.

${ }^{52}$ In view of the limited remnants of the text, it is not possible to determine its genre with any exactitude, and I use the phrase 'penitential prayer' in a loose sense. The lack of direct address to God and the absence of petition may or may not be due to the fragmentary state of the text.
} 